\title{
BIOSIMILARS IN INFLAMMATORY BOWEL DISEASES: an important moment for Brazilian gastroenterologists
}

\author{
Fábio Vieira TEIXEIRA', Paulo Gustavo KOTZE², Aderson Omar Mourão Cintra DAMIÃO³ \\ and Sender Jankiel MISZPUTEN ${ }^{4}$
}

\begin{abstract}
Biosimilars are not generic drugs. These are more complex medications than small molecules, with identical chemical structures of monoclonal antibodies that lost their patency over time. Besides identical to the original product at the end, the process of achieving its final forms differs from the one used in the reference products. These differences in the formulation process can alter final outcomes such as safety and efficacy of the drugs. Recently, a biosimilar of Infliximab was approved in some countries, even to the management of inflammatory bowel diseases. However, this decision was based on studies performed in rheumatologic conditions such as rheumatoid arthritis and ankylosing spondylitis. Extrapolation of the indications from rheumatologic conditions was done for Crohn's disease and ulcerative colitis based on these studies. In this article, the authors explain possible different mechanisms in the pathogenesis between rheumatologic conditions and inflammatory bowel diseases, that can lead to different actions of the medications in different diseases. The authors also alert the gastroenterological community for the problem of extrapolation of indications, and explain in full details the reasons for being care with the use of biosimilars in inflammatory bowel diseases without specific data from trials performed in this scenario.
\end{abstract}

HEADINGS - Biosimilar pharmaceuticals. Crohn disease. Ulcerative colitis.

\section{INTRODUCTION}

As time goes by, innovator biological products lose patent protection and other pharmaceutical companies start to develop copies of the reference product. Specially in Europe, the term 'biosimilar' is recognized by both regulatory agents and stakeholders. Its synonyms include: similar biotherapeutic products, used by the World Health Organisation (WHO) and subsequent-entry biologics (SEB), used in Canada

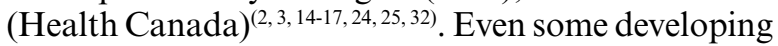
countries, as Brazil, have a specific legislation to deal with the biosimilar products ${ }^{(1,5,10,12,13,20,23,27)}$.

Biosimilars are not generic drugs. Generic drugs have a simple chemical structure (sometimes called small molecules) and can be copied exactly as the innovator reference product ${ }^{(10,20,22,23)}$. In contrary, biologics are complex molecules produced in live organisms (animal or vegetal cells, bacteria or yeast) with a molecular weight varying from 100 to 20.000 times heavier than a chemical molecule (for example, a molecule of aspirine has $65 \mathrm{kDa}$ while a monoclonal antibody can have
$25.000 \mathrm{kDa}$ ). In fact, biosimilar products are similar, but not identical to the reference agent.

Since their first approval in 2005, several biosimilars of somatropin (human growth hormone), filgrastim (granulocyte colony-stimulating factor, G-CSF) and epoetin (erythropoietin) have become available in Europe. However, these are less complex structure chemicals and have low molecular weight as compared to a complex molecule, as some monoclonal antibodies $^{(14-17)}$.

Recently in Europe, the patent of Infliximab (IFX) expired and the European Medicines Agency (EMA) has already approved a biosimilar of this agent for their market ${ }^{(19)}$. However, even after patent expiration, manufacturing processes do not have to be disclosed, and there can be appreciable differences in the manufacturing processes of biosimilars and their reference products ${ }^{(10,12,19,20,22)}$. As this reality is pretty close to the Latin American market, not only in the rheumathology and dermatology fields, it is clear that biosimilars turned into a subject to be discussed also by gastroenterological societies ${ }^{(10,12)}$.

This article did not have any funding source.

Disclosure: FT, PK, AD and SM are speakers and consultants for Abbvie and Janssen-Cilag. AD is an employee for Nestle.

Clínica Gastrosaúde - Marília, SP; ${ }^{2}$ Serviço de Coloproctologia do Hospital Universitário Cajuru - SeCoHUC - PUCPR, Curitiba, PR; ${ }^{3}$ Serviço de Gastroenterologia da Faculdade de Medicina da Universidade de São Paulo - FMUSP, São Paulo, SP; ${ }^{4}$ Serviço de Gastroenterologia da Escola Paulista de Medicina - UNIFESP, São Paulo, SP. Brasil

Correspondence: Dr. Paulo Gustavo Kotze. Rua Mauá, 682. CEP: 80030-200. Curitiba, PR, Brasil. E-mail: pgkotze@hotmail.com 


\section{PRODUCTION OF IFX BIOSIMILAR: possible differences to the reference product}

As previously stated, biosimilar products are not generic drugs. So, it is likely that possible differences in the manufacturing process can lead to significant differences in terms of outcomes in comparison to the reference agent. Production of biosimilars is associated with several challenges. Molecular heterogeneity of biological agents results from the complex interplay of the primary, secondary and higher-order structures. Intra and inter molecular interactions and post-translational modifications result in millions of chemical forms ${ }^{(13,19,27)}$. As an example, antibodies must have to be glycosylated in their Fc region. This makes the tridimensional structure of a monoclonal antibody molecule much more complex. The type and degree of glycosylation has a major influence on the interaction with Fc receptors, and such changes in the glycosylation pattern could lead to unpredictable effects on efficacy, safety and immunogenicity. EMA in 2013 and Health Canada in the beginning of 2014, analyzed the submission dossier of the IFX biosimilar (Remsima $^{\mathrm{TM}}$ - EU and Inflectra ${ }^{\mathrm{TM}}$ - Canada). Some differences where found in the biosimilar as compared to the reference product (IFX, REMICADETM, Janssen, USA) ${ }^{(13,23)}$. Some alterations were observed, such as a different level of afucosylation, differences in Fc $\gamma$ RIIIa receptor binding, and some in vitro abnormalities in Antibody-Dependent Cell-Mediated Cytotoxicity (ADCC) $)^{(13,23)}$. This means that even an identical molecule, due to different pathways to the final aspect of the chemical compound, can result in a different function, and that can alter the clinical outcome to our patients.

\section{IFX FOR RHEUMATOID ARTHRITIS AND INFLAMMATORY BOWEL DISEASES: same drug, different pathophysiology and different mechanism of action}

Anti-TNF agents, IFX and Adalimumab (ADA), may have two possible different mechanisms of action to block TNF: blockade of TNF receptor-mediated mechanisms and induction of tmTNF-mediated mechanisms. Both, soluble TNF (sTNF) and transmembrane (tmTNF) ligands interact with either of two distinct receptors: TNF receptor 1 (TNFR1) (p55, CD120a) and TNFR2 (p75, CD120b) ${ }^{(8,18)}$. In rheumatoid arthritis (RA), IFX is thought to act predominantly through the neutralization of sTNF and tmTNF. By blocking TNF, IFX also block TNF biological activity: cytokines and chemokine production, cell activation, cell recruitment, angiogenesis, bone destruction, cartilage degradation and fibroblast proliferation. Antigen neutralization requires only binding through the Fab region, whereas antibody-dependent cell-mediated cytotoxicity (ADCC) requires binding to the antigen through the Fab region along with binding to Fcy RIIIa receptors, on effector cells through the $\mathrm{Fc}$ region. Considerable uncertainty exists regarding the extent to which the Fc domain of IFX contributes to the mechanism of action in different indications, such as rheumatologic conditions and inflammatory bowel diseases (IBD) $^{(12,28,29,31)}$.

IFX, ADA and golimumab (GOL) are full-length, bivalent IgG monoclonal antibodies. Certolizumab pegol (CZP) is a monovalent Fabl antibody fragment covalently linked to polyethylene glycol to increase the half-life of the molecule. Another anti-TNF agent, etanercept, is a genetically engineered fusion protein composed of a dimer of the extracellular portions of human TNFR2 fused to the Fc portion of human IgG1. Although the amino acid sequences of the $\mathrm{Fc}$ regions are identical, the markedly shorter plasma half-life of etanercept versus IgG1 monoclonal antibodies or other Fc fusion proteins suggests that the conformation or steric accessibility of the $\mathrm{Fc}$ region of etanercept may be different from those of the $\mathrm{Fc}$ regions of the IgG1 antibodies IFX and ADA. As a result of that, etanercept is approved to treat RA due to its significant efficacy. On the other hand, the same efficacy was not proved in Crohn's disease, mainly due to this slight difference in its mechanism of action at the molecular level in these different diseases ${ }^{(30,31)}$.

In the treatment of IBD, there is robust evidence that IFX, ADA, CZP and more recently GOL, have dual functions and may act as antagonists by blocking tmTNF interactions with TNFR $1 / 2$, or as agonists by initiating reverse signaling, leading to apoptosis, cell activation or cytokine suppression $^{(21,30,31)}$. In summary, in contrary to the scenario of RA, in which anti-TNF acts preferentially blocking sTNF and tmTNF, in IBD, it seems that reverse signaling initiated by TNF antagonists, through tmTNF or cytotoxicity of the tmTNF-bearing cell by CDC or ADCC is emerging as a mechanism that may be important to apoptosis, cytokine suppression and/or other cellular events ${ }^{(28,29)}$.

\section{SHOULD WE EXTRAPOLATE THE INDICATION TO IBD FOR A BIOSIMILAR APPROVED IN RA?}

The answer is no, not yet. This opinion is in agreement of the position of several other specialists and gastroenterological societies worldwide ${ }^{(10,12,19,20,27,28)}$.

Celltrion's biosimilar of IFX (CT-P13, Remsima ${ }^{\mathrm{TM}}$ ) is already being manufactured and marketed in South Korea, where it was approved for all indications of the reference product, including all rheumatologic conditions and $\mathrm{IBD}^{(4,26,27)}$. Surprisingly for all gastroenterological societies worldwide, even ECCO (European Crohn's and Colitis Organisation), in 2013 EMA approved Remsima ${ }^{\mathrm{TM}}$, under the same INN (name of the drug) of the reference product: "infliximab" $(10,12,19)$. EMA's approval was for all indications of the reference product Remicade ${ }^{\mathrm{TM}}$. The European agency's decision was based on two trials of patients with rheumatic conditions: a phase I clinical trial (PLANETAS) was carried out in patients with ankylosing spondylitis (AS), whereas equivalence in safety and efficacy was demonstrated to the IFX reference product in a phase III study (PLANETRA) during co-administration of methotrexate in patients with RA $^{(29,33)}$. EMA approved the use of CT-P13 for all indications of Remicade ${ }^{\mathrm{TM}}$ based on the results of these rheumatology 
$\operatorname{trials}^{(13)}$. On the other hand, 6 months later, Health Canada was much more conservative in a much more careful and wise decision. The Canadian agency just approved Inflec$\operatorname{tra}^{\mathrm{TM}}$ (Celltrion Healthcare Co. Ltd.) for RA and for AS, the indications that had specific trials to prove the efficacy and safety of the drug in defined scenarios. The agency did not extrapolate the indication for plaque psoriasis and adult and pediatric IBD (Crohn's disease and ulcerative colitis). The rationale for Heath Canada decision, in agreement with the opinion of several specialists worldwide, was based on three critical points: study design and population used in the phase I and III trials, ADCC and FcrRIIIa binding differences between Inflectra and the reference product, and finally, the uncertainty regarding the safety profile in the IBD

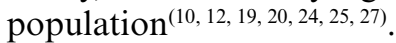

\section{Study design and population}

The sponsor of the trials should provide solid answers for the doubt on the subject or patient groups chosen for clinical pharmacological studies that can provide the most sensitive measurement of differences between the proposed biosimilar and the reference products. If the difference in efficacy between a treatment and placebo is small, it is difficult to demonstrate a significant difference between the treatment and another similar treatment arm in one trial. From the six indications of IFX, the greatest placebo-adjusted response was found in plaque psoriasis, followed by psoriatic arthritis and Crohn's disease. In contrast, RA was associated with the smallest placebo-adjusted response to IFX. However, the main equivalence trial with the IFX biosimilar used to extrapolate indications was performed in RA patients. In fact, the similar efficacy between CT-P13 and the reference IFX in RA may not rule out the possibility that the efficacies of the two products are different in other extrapolated indications, in which such differences can be more easily detected because they have more sensitive clinical models than RA. It will be always present Carl Segan's aphorism: "absence of evidence is not evidence of absence"(3,10,12, 19,23).

\section{ADCC and Fc $\gamma$ RIIla binding differences}

Considering biosimilars and the reference products, it has being observed differences in the level of afucosylation, Fc $\gamma$ RIIIa receptor binding, and some in vitro Antibody-Dependent Cell-Mediated Cytotoxicity (ADCC) assays. Such differences in the ability of the two products to induce ADCC could not be ruled out from the outcomes of the two agents. The biosimilar manufacturer provided rationale to support their position that ADCC is not an important mediator of the efficacy of their product (or of Remicade ${ }^{\mathrm{TM}}$ ). Therefore, as already previously discussed, ADCC cannot be ruled out as a mechanism of action in IBD. This position is supported by the observation that CZP, another anti-TNF that does not have the ability to induce ADCC, displays only marginal efficacy in Crohn's patients as compared to other anti-TNFs, namely IFX. The Canadian agency concluded that, "since differences in ADCC have been observed between the two products and because ADCC may be an active mechanism of action for IFX in the setting of IBD, but not in the setting of rheumatic diseases (the studied populations), extrapolation from the settings of RA and AS to IBD cannot be recommended due to the absence of clinical studies in IBD"(23). Moreover, the differences observed in the Fc $\gamma$ RIIIa binding and, subsequently, ADCC, do not preclude extrapolation from the settings of RA and AS to the other requested indications of psoriatic arthritis and plaque psoriasis.

\section{Safety profile of biosimilar in IBD patients}

The safety data of CT-P13 were collected in the three clinical trials that were performed: the pilot phase I trial in RA patients, the pivotal pharmacokinetics trial in AS patients, and the pivotal efficacy trial in RA patients ${ }^{(13,29,33)}$. The safety analysis was performed on the safety population defined as all patients who received at least one full or partial dose during any dosing period. The safety monitoring included adverse events, serious adverse events, treatment-emergent adverse events (TEAEs), serious TEAEs, death, hypersensitivity via vital signs, electrocardiogram (ECG) alterations, alterations in physical examination and clinical laboratory tests, concomitant medications, signs and symptoms of tuberculosis (TB), and pregnancy. Infections, infusion-related reactions and safety issues of special interest for IFX were also closely monitored $^{(13)}$. The areas of special interest were heart failure, serious infections (including TB, Hepatitis B viral infections reactivation, sepsis and opportunistic infections) as well as serious infusion reactions, delayed hypersensitivity reactions (serum sickness), systemic lupus erythematosus/lupus-like syndrome, hepatobiliary events, demyelinating disorders (i.e. multiple sclerosis, Guillain-Barré syndrome), haematologic reactions and lymphoma (including hepatosplenic T-cell lymphoma). Of the 871 patients included in the safety population, all had rheumatic conditions, a total of 721 patients with RA and 250 with AS. None had any adult or pediatric form of IBD ${ }^{(29,33)}$. Celltrion just provided preliminary safety and clinical data from a very small cohort of 23 patients with IBD, 15 patients with Crohn's disease and 8 with ulcerative colitis, in which they indicate similar response to these conditions with CT-P13 as compared with historical data of the reference IFX product ${ }^{(13,23)}$. The pharmaceutical company has extended the enrolment of IBD patients in this post-marketing surveillance study and will conduct an additional comparative trial versus Remicade ${ }^{\mathrm{TM}}$ in active Crohn's disease. There is still lack of information regarding a post-marketing publication with safety and efficacy results in patients with IBD under CT-P13 treatment.

\section{HOW TO POSITION IBD IN THE BIOSIMILARS SCENARIO?}

It has been shown in clinical trials that the IFX biosimilar (REMSIMA ${ }^{\mathrm{TM}}$ - EU and INFLECTRA ${ }^{\mathrm{TM}}$ - Canada) has efficacy and safety equivalent to reference product 
(IFX, REMICADE ${ }^{\mathrm{TM}}$, Janssen, USA) in patients with rheumatologic conditions ${ }^{(6,7,29,33)}$. EMA in Europe and Health Canada used these data to support their decisions to approve these agents in their countries. EMA extrapolated the approval for IBD. On the other hand, Health Canada did not ${ }^{(13,23,24,25)}$.

Biosimilars are biological products produced in live systems. Monoclonal antibodies are one the most complex example of biosimilars with a glycosylated tridimensional structure molecule with a molecular weight at least 1000 times heavier than a less complex product as epoetin, for example. Despite the biological reference drug patent expiration, some details of the manufacturing process are still an important secret in intelligence scenarios of the pharmaceutical industry. For a biological drug, the entire process determines the quality attributes of the product, and therefore, a biosimilar can never be considered fully identical to its reference product ${ }^{(11)}$. As it has been reported, some differences between biosimilars and the reference products were expected.

Recently, an ECCO Board published online a 15-question multiple choice anonymous web survey performed with randomly selected society members invited to participate by email. The 15 questions covered most relevant aspects on biosimilars. The results of this survey showed that the majority of responders are reluctant to accept data from clinical trials conducted in rheumatologic indications as valid for IBD and wish to base their opinion on disease-specific evidence. At the moment, between ECCO members, confidence in prescribing biosimilars in IBD remains low, although they seem to be adequately informed. It was almost unanimous that IBD-specific data on the comparison for efficacy, safety, and immunogenicity are urgently needed ${ }^{(9)}$.

In an important opinion from Latin America, Morton Scheinberg (a rheumatology researcher) wisely stated: "while abbreviated pathways of approval will impact the final price of a biosimilar we feel that extrapolation to IBD without a comparative trial is a controversial decision that may not have all the immunopathogenic rationale that one would expect in taking care of such patients" (30). Scheinberg's opinion is in accordance to the majority of the academic community, that comparable trials should be performed between the reference biologic and the biosimilar in IBD before they get marketing authorization for use in clinical practice ${ }^{(9,10,12,18-20,33)}$.

In summary, regarding the extrapolation of the approval of a biosimilar to such a different indication as IBD, important conclusions can be made, in accordance to the ECCO position $^{(10)}$ :
1. The molecular size and complex structure of biological medicines (and biosimilars) make it extremely difficult to predict therapeutic equivalence, because even subtle changes during development can cause significant differences in clinical efficacy or immunogenicity. Such differences can occur even within the same biological medicine if different manufacturing processes are used (e.g. different cell lines).

2. Rules applied to the production of generic chemical medicines cannot be transferred to biosimilars.

3. Different biological and biosimilar medicines targeting the same molecule are neither identical in efficacy nor toxicity, even in the same clinical entity.

4. A biosimilar proven effective and safe for one indication may not necessarily be effective and safe for a second indication for which the reference biological has been shown to be safe and effective.

5. Specific evidence obtained in patients with IBD should be required to establish efficacy and safety for this specific indication, because experience with currently licensed biological medicines has already shown that clinical efficacy in IBD cannot be predicted by effectiveness in other indications, such as rheumatoid arthritis.

6. Clinical trials should be of large enough size to detect common adverse events and powered to show equivalence with a reference biological agent, or conventional superiority.

7. Post-marketing collection of data in both children and adults is necessary to confirm safety by recording less common but important potential adverse effects, as well as identifying any increase in frequency of predictable adverse events contingent on wide access to treatment.

8. Any decision to substitute a product should only be made with the prescribing health care provider's specific approval and patient's knowledge.

Studied carried out at Clínica Gastrosaúde (Marília - SP - Brazil), Serviço de Coloproctologia do Hospital Universitário Cajuru - PUCPR (Curitiba - PR - Brazil), Serviço de Gastroenterologia da Faculdade de Medicina da Universidade de São Paulo (FMUSP - São Paulo - SP - Brazil) and Serviço de Gastroenterologia da Escola Paulista de Medicina (UNIFESP - São Paulo - SP - Brasil).

\section{Author contribution}

Teixeira FV and Kotze PG drafted the article. Damião AOMC and Miszputen SJ reviewed it and gave important intellectual content and collaboration to the final version of the manuscript. 
Teixeira FV, Kotze PG, Damião AOMC, Miszputen SJ. Biosimilares nas doenças inflamatórias intestinais: um momento importante para os gastroenterologistas brasileiros. Arq Gastroenterol. 2015,52(1):76-80.

RESUMO - Biosimilares não são medicamentos genéricos. Trata-se de medicamentos mais complexos do que moléculas pequenas, com estrutura química idêntica a anticorpos monoclonais que perderam sua patente. A despeito de serem idênticas ao produto original, há significativas diferenças no processo de composição entre as mesmas em relação ao produto de referência. Essas diferenças no processo podem alterar desfechos importantes como a eficácia e segurança dessas drogas. Recentemente, um biosimilar do Infliximabe foi aprovado em alguns países, para utilização no cenário das doenças inflamatórias intestinais. Essa decisão foi tomada baseada em estudos realizados no cenário da reumatologia, em artrite reumatóide e espondilite anquilosante. A extrapolação das indicações reumatológicas foi feita para o cenário das doenças inflamatórias intestinais por dados desses estudos, com aprovação para as mesmas em algumas agências reguladoras. Neste artigo, os autores explicam os possíveis diferentes mecanismos na fisiopatologia das doenças reumatológicas e intestinais, que podem resultar em` diferentes mecanismos de ação das drogas em diferentes cenários. Os autores alertam a comunidade gastroenterológica para o problema da extrapolação de indicações e explicam detalhadamente as razões para se ter cuidado com o uso de biosimilares nas doenças inflamatórias intestinais sem evidências científicas adequadas obtidas em estudos especificamente nesse cenário.

DESCRITORES - Medicamentos biossimilares. Doença de Crohn. Colite ulcerativa.

\section{REFERENCES}

1. ANVISA. [Internet]. Registro de Produtos Biológicos. Bases Legais e Guias - Coletânea. Resolução - RDC n 55, de 16 de dezembro de 2010. Available from: http://portal.anvisa.gov.br/wps/wcm/connect/935aed0048bd2755a $7 \mathrm{cda}$ f9a6e94f0d0/Registro_Produtos_Biologicos_Hemoterapicos_10102011_WEB. pdf?MOD=AJPERES

2. Azevedo VF. Biossimilares necessitam de dados clínicos comparativos cientificamente confiáveis. Rev Bras Reumatol. 2013;53(1):127-31.

3. Biologics Price Competition and Innovation Act of 2009, H.R. 3590-687, Licensure of Biological Products as Biosimilar or Interchangeable. [Accessed 02.09.14]. Available from: http://www.fda.gov/downloads/drugs/guidancecomplianceregulatoryinformation/ucm216146.pdf

4. Biosimilar News. [Internet]. World's first biosimilar antibody is approved in Korea; 2012 Jul 23. [Accessed 2013 Ap 04]. Available from: http://www.biosimilarnews. $\mathrm{com} /$ worlds-first- biosimilar-antibody-is-approved-in-korea

5. Castanheira LG, Barbano DB, Rech N. Current development in regulation of similar biotherapeutic products in Brazil. Biologicals. 2011;39(5):308

6. Celltrion Healthcare Co. Ltd. [Internet]. INFLECTRA (infliximab). Product Monograph. [cited 2013 Ap 04]. Available from: http://fresenius-kabi.ca/en/ wp-content/uploads/sites/2/2014/04/Remsima product-monograph.pdf

7. Celltrion Healthcare Co. Ltd. [Internet]. REMSIMA (infliximab). Product Monograph. [Accessed 2013 Ap 04]. Available from: http://fresenius-kabi.ca/en/ wp-content/uploads/sites/2/2014/04/Remsima_product-monograph.pdf

8. Chen, HA, Lin, KC, Chen, CH, Liao, HT, Wang, HP, Chang, HN, et al. The effect of etanercept on anti-cyclic citrullinated peptide antibodies and rheumatoid factor in patients with rheumatoid arthritis. Ann Rheum Dis. 2006;65:35-9.

9. Danese S, Fiorino G, Michetti P. Viewpoint: knowledge and viewpoints on biosimilar monoclonal antibodies among members of the European Crohn's and Colitis Organization. J Crohns Colitis. 2014;8(11):1548-50.

10. Danese S, Gomollon F. ECCO position statement: the use of biosimilar medicines in the treatment of inflammatory bowel disease (IBD). J Crohns Colitis. 2013;7(7):586e9.

11. Decleck PF. Biological and biosimilars: is similar the same? J Crohns Colitis. 2013;8:S427.

12. Devlin SM, Bressler B, Bernstein CN, Fedorak RN, Bitton A, Singh H, et al Overview of subsequent entry biologics for the management of inflammatory bowel disease and Canadian Association of Gastroenterology position statement on subsequent entry biologics. Can J Gastroenterol. 2013;27(10):567e71.

13. European Medicines Agency recommends approval of first two monoclonal antibody biosimilars. [Internet]. Recommendation marks extension of biosimilar concept to new product-class. [Accessed 2013 Ap 04]. Available from: http:// www.ema.europa.eu/docs/en_GB/document_library/Press_release/2013/06/ WC500144941.pdf

14. European Medicines Agency. [Internet]. Applications for new human medicines under evaluation by the Committee for Medicinal Products for Human Use, November 2012. 2012 Nov 14. [Accessed 2013 Ap 04]. Available from: http:// ec.europa.eu/health/files/paediatrics/2012_report_paed_regulation.pdf.

15. European Medicines Agency. [Internet]. Biosimilar medicines. 2012. 2012 Nov 14. [Accessed 2013 Ap 04]. Available from: http://www.ema.europa.eu/ema/index. jsp?curl=pages/regulation/general/general_content_000408.jsp

16. European Medicines Agency. [Internet]. European Assessment Reports for authorized medicinal products for human use. 2012. 2012 Nov 14. [Accessed 2013 Ap 04]. Available from: http://www.ema.europa.eu/ema/index.jsp?curl=pages/ medicines/general/general_content_000433.jsp

17. Expert Committee on Biological Standardization, World Health Organization. [Internet]. Guidelines on evaluation of similar biotherapeutic products. [Accessed
2014 Ap 02]. Available from: http://www.who. int/biologicals/areas/biological_therapeutics/BIOTHERAPEUTICS_FOR_WEB_22APRIL2010.pdf; 2009

18. Feagan BG, Choquette D, Ghosh S, Gladman DD, Ho V, Meibohm B, et al The challenge of indication extrapolation for infliximab biosimilars. Biologicals. 2014;42(4):177-83.

19. Gecse KB, Khanna R, van den Brink GR, Ponsioen CT, Löwenberg M, Jairath V, Travis SPL, Sandborn WJ, Feagan BG, D'Haens GRAM. Biosimilars in IBD: hope or expectation? Gut. 2013;62(6):803-7.

20. Ghosh S. Subsequent entry biologics e opportunities and challenges. Can J Gastroenterol. 2013;27(10):565.

21. Gramlick A, Fossati G, Nesbitt AM. Neutralization of soluble and membrane tumor necrosis factor-alpha (TNF- alpha) by infliximab, adalimumab, or certolizumab pegol using P55 or P75 TNF-alpha receptor- specific bioassays. Gastroenterology. 2006;130(4):A697.

22. Guidance for Industry. [Internet]. Clinical Pharmacology Data to Support a Demonstration of Biosimilarity to a Reference Product. [Accessed 27.09.14]. Available from: http://www.fda.gov/downloads/Drugs/GuidanceComplianceRegulatoryInformation/Guidances/UCM397017.pdf

23. Health Canada. [Internet]. Summary Basis of Decision (SBD) documents provide information related to the original authorization of a product: Inflectra. Accessed 2013 Ap 04]. Available from: http://www.hc-sc.gc.ca/dhp-mps/prodpharma/sbdsmd/drug-med/sbd_smd_2014_inflectra_159493-eng.php [

24. Health Products and Food Branch, Health Canada. [Internet]. Guidance for sponsors: information and submission requirements for subsequent entry biologics (SEBs). [Accessed 2014 Sept 27]. Available from: http://www.hc-sc.gc.ca/dhp-mps/ alt_formats/pdf/brgtherap/applic-demande/guides/seb-pbu/seb-pbu-2010-eng.pdf; 2010.

25. Janssen Biologics B.V. [Internet]. REMICADE (infliximab) summary of product characteristics. 2013. [Accessed 2014 Feb 01]. Available from: http://www. ema.europa.eu/docs/en_GB/document_library/EPAR_-_Product_Information/ human/000240/WC500050888.pdf.

26. Korea Food and Drug Administration. National Institute of Food and Drug Safety Evaluation. Guidelines on the evaluation of biosimilar products. Chungcheongbuk-do: Korea Food and Drug Administration; 2010.

27. Lee $\mathrm{H}$. Is extrapolation of the safety and efficacy data in one indication to another appropriate for biosimilars? AAPS J. 2013;16:22e6.

28. McInnes IB, Schett G. The pathogenesis of rheumatoid arthritis. N Engl J Med. 2011;365(23):2205-19.

29. Park W, Hrycaj P, Jeka S, Kovalenko V, Lysenko G, Miranda P, et al. A randomised, double-blind, multicentre, parallel-group, prospective study comparing the pharmacokinetics, safety, and efficacy of CT-P13 and innovator infliximab in patients with ankylosing spondylitis: the PLANETAS study. Ann Rheum Dis. 2013;72(10):1605-12.

30. Scheinberg M. Biosimilars in Crohn's disease. J Crohns Colitis. 2014;8(7):71.

31. Tracey D, Klareskog L, Sasso EH, Salfeld JG, Tak PP. Tumor necrosis factor antagonist mechanisms of action: a comprehensive review. Pharmacol Ther. 2008; 117:244-79.

32. Tsiftsoglou AS, Ruiz S, Schneider CK. Development and regulation of bio- similars: current status and future challenges. BioDrugs. 2013;27(3):203e11.

33. Yoo DH, Hrycaj P, Miranda P, Ramiterre E, Piotrowski M, Shevchuk S, et al. A randomised, double-blind, parallel-group study to demonstrate equivalence in efficacy and safety of CT- P13 compared with innovator infliximab when coadministered with methotrexate in patients with active rheumatoid arthritis: the PLANETRA study. Ann Rheum Dis. 2013;72(10):1613-20.

Received 18/10/2014 Accepted 20/10/2014 